\title{
Rapunzel syndrome: a tail too long to tell!
}

\author{
Kashish Khanna, ${ }^{1}$ Sarvesh Tandon, ${ }^{2}$ Devendra Kumar Yadav, ${ }^{1}$ Vikram Khanna ${ }^{3}$
}

${ }^{1}$ Department of Pediatric Surgery, All India Institute of Medical Sciences, New Delhi, India

${ }^{2}$ Forensic Medicine, Vardhaman Mahavir Medical College and Safdarjang Hospital, New Delhi, India

${ }^{3}$ Pediatric Surgery, Lady Hardinge Medical College, New Delhi, India

Correspondence to Dr Vikram Khanna, vikramaiims@gmail.com

Accepted 21 March 2018
Check for updates

To cite: Khanna K, Tandon S, Yadav DK, et al. BMJ Case Rep Published Online First: [please include Day Month Year]. doi:10.1136/bcr-2018224756

\section{DESCRIPTION}

Trichobezoar leading to Rapunzel syndrome (RS) is an extremely rare entity with about 90 cases reported in literature. ${ }^{1}$ RS derives its name from the fairy tale 'Rapunzel', where the German princess let her long golden hair down from her tower to facilitate a tryst with her lover akin to the long and shiny tail of hair seen in RS. ${ }^{2}$ Hair being slippery gets trapped in gastric mucosal folds, eluding peristalsis. More and more hair conglomerate to form a stomach-shaped mass coated with mucus called trichobezoar. This provides it a shiny glistening surface, and the acid secreted in stomach denatures the hair protein which gives it the typical black colour. ${ }^{3}$ When the tail of hair extends beyond the stomach into the small intestine, it is called RS.

A 6-year-old girl presented to our emergency department with history of abdominal pain and recurrent vomiting for 3-4 days. On examination she was dehydrated, had tachycardia and looked malnourished. Her abdomen was grossly distended without signs of peritonitis. An X-ray abdomen (erect) showed four-air-fluid levels suggestive of acute small bowel obstruction. With the provisional diagnosis of band obstruction, she was taken up for exploratory laparotomy after stabilisation.

On exploration, the stomach was grossly distended with a palpable semisolid mass inside it which seemed to continue into the duodenum, jejunum and up till the mid-ileum. Beyond this, the ileum and colon seemed normal in calibre. On gastrotomy, a giant trichobezoar was found in the stomach which was removed carefully (figure 1A,B). The long tail of the bezoar continued till mid-ileum and was removed

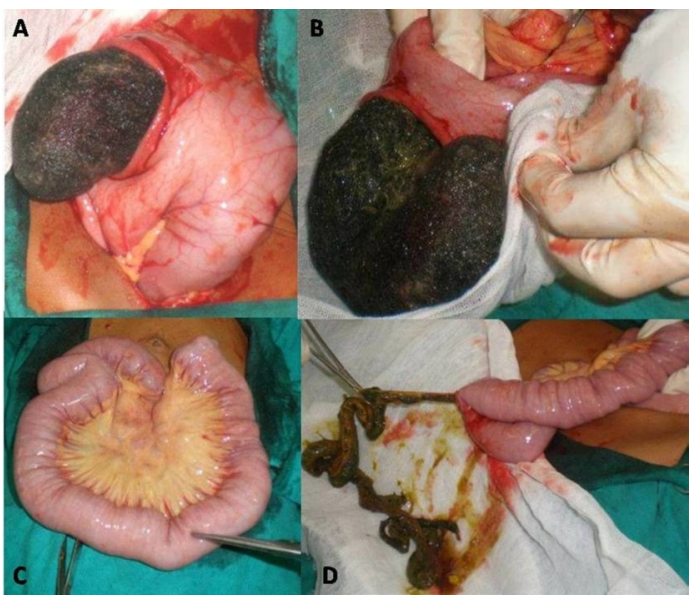

Figure 1 (A) Gastrotomy revealed large trichobezoar; (B) removal of trichobezoar through gastrotomy; (C) extended tail of trichobezoar causing distension of the small intestine up till mid ileum; (D) enterotomy and removal of the entire Rapunzel's tail of hair. partly through the gastrotomy and partly through a separate enterotomy (figure 1C,D). The entire tail of hair was delivered without any free spill in the peritoneal cavity. Both the gastrotomy and enterotomy were repaired primarily in two layers. The hair ball weighed $2100 \mathrm{~g}$, measured approximately $11 \mathrm{~cm} \times$ $16 \mathrm{~cm}$ in size, and its tail extended about $110 \mathrm{~cm}$ in length distally into the jejunum and ileum (figure 2).

Retrospectively, parents gave history that their girl used to play with her hair and put them in her mouth since childhood, which she probably swallowed. However, they gave no history of any psychiatric illness. She had decreased appetite, early satiety and poor weight gain since childhood. On specific examination, her hair were sparse with the presence of flag sign, and she weighed below 50th percentile for her age. This history explained the sequence of events; trichotillomania followed by trichophagia, eventually leading to trichobezoar with its tail of hair extending beyond the stomach and causing acute intestinal obstruction. Hence, RS was diagnosed. The recovery was uneventful, and the child was discharged on day 7 after psychiatric evaluation. On follow-up after 1 month, she had no surgical complaints; however, behaviour therapy and counselling for trichotillomania, and a high protein diet for nutritional build-up were advised.

RS is commonly seen in young females like in our case; majority have some associated psychiatric disorders like trichotillomania. The most common symptoms and signs are abdominal pain (37\%), nausea and vomiting (33.3\%), obstruction (25.9\%) and peritonitis $(18.3 \%)$, and the less common ones are weight loss (7.4\%), anorexia, haematemesis and intussusceptions $(7.4 \%) .^{2} \mathrm{~A}$ few cases present with complications like obstructive jaundice, pancreatitis, gastric ulcer, appendicitis and gut perforation. ${ }^{1}$

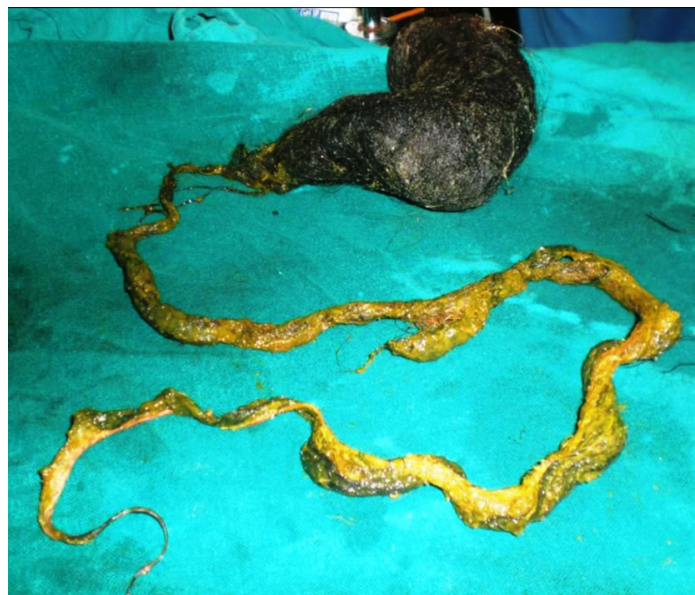

Figure 2 The entire specimen put together in toto; the long Rapunzel's tail of hair is seen clearly. 
Abdominal examination typically reveals an upper abdominal mass (Lamerton's sign). Radiological investigations like ultrasound, dye study and CT scan can clinch the diagnosis preoperatively. Endoscopy is both diagnostic and therapeutic. Laparoscopic removal is possible though not always feasible as the tail often extends into the jejunum. Hence, laparotomy is the preferred approach especially in emergent cases similar to ours. $^{24}$

A comprehensive and long-term psychiatric follow-up is needed in all cases as late relapse is possible. Apart from behaviour therapy, pharmacotherapy (clomipramine, quetiapine

\section{Learning points}

- Rapunzel syndrome is an extremely rare form of trichobezoar commonly seen in young females who are in a habit of eating hair.

- Acutely symptomatic, large trichobezoars, especially when accompanied by Rapunzel syndrome, must be removed surgically preferably by laparotomy or by laparoscopy.

- Comprehensive and long-term psychiatric follow-up is of utmost importance to prevent recurrence or late relapse of this condition.

- Patients presenting with signs or symptoms of intestinal obstruction should be examined thoroughly for psychiatric conditions and broken hair to rule out the rare possibility of trichotillomania. or augmenting a selective serotonin reuptake inhibitor with an atypical antipsychotic effect) may be needed in recurrent or resistant cases. ${ }^{4}$

Contributors The case was admitted and operated under the care of DKY at Safdarjung Hospital. The manuscript was envisaged and written by KK. The pictures were collected by DKY and VK. All authors contributed to the drafting of the manuscript. ST helped in the final editing of the revised manuscript. All authors approved the submission of the revised version.

Funding The authors have not declared a specific grant for this research from any funding agency in the public, commercial or not-for-profit sectors.

Competing interests None declared.

Patient consent Parental/guardian consent obtained.

Provenance and peer review Not commissioned; externally peer reviewed.

(c) BMJ Publishing Group Ltd (unless otherwise stated in the text of the article) 2018. All rights reserved. No commercial use is permitted unless otherwise expressly granted.

\section{REFERENCES}

1 Ullah W, Saleem K, Ahmad E, et al. Rapunzel syndrome: a rare cause of hypoproteinaemia and review of literature. BMJ Case Rep:bcr2016216600 (accessed 12 Sep 2016)

2 Wang Z, Cao F, Liu D, et al. The diagnosis and treatment of Rapunzel syndrome. Acta Radiol Open 2016;5:20.

3 Kajal P, Bhutani N, Tyagi N, et al. Trichobezoar with and without Rapunzel syndrome in paediatric population: A case series from a tertiary care centre of Northern India. Int J Surg Case Rep 2017;40:23-6.

4 Obinwa O, Cooper D, Khan F, et al. Rapunzel syndrome is not just a mere surgical problem: A case report and review of current management. World J Clin Cases 2017;5:50-5.

Copyright 2018 BMJ Publishing Group. All rights reserved. For permission to reuse any of this content visit

http://group.bmj.com/group/rights-licensing/permissions.

BMJ Case Report Fellows may re-use this article for personal use and teaching without any further permission.

Become a Fellow of BMJ Case Reports today and you can:

- Submit as many cases as you like

- Enjoy fast sympathetic peer review and rapid publication of accepted articles

- Access all the published articles

Re-use any of the published material for personal use and teaching without further permission

For information on Institutional Fellowships contact consortiasales@bmjgroup.com

Visit casereports.bmj.com for more articles like this and to become a Fellow 